\title{
The impact of trade with China and India on Argentina's manufacturing employment *
}

\author{
Lucio Castro* \\ Marcelo Olarreaga \\ Daniel Saslavsky
}

\begin{abstract}
For many in Latin America, the increasing participation of China and India in international markets is seen as a looming shadow of two 'mighty giants' on the region's manufacturing sector. Are they really mighty giants when it comes to their impact on manufacturing employment? This paper attempts to answer this question by estimating the effects of trade with China and India on Argentina's industrial employment. We use a dynamic econometric model and industry level data to estimate the effects of trade with China and India on the level of employment in Argentina's manufacturing sector. Results suggest that trade with China and India only had a small negative effect on industrial employment, even during the swift trade liberalization of the 1990s.
\end{abstract}

Key words: China, Latin America, Trade, Import Competition, Trade and Labor Market Interactions, Employment

JEL Classification: F14, F15, F16, F17, L60.

World Bank Policy Research Working Paper 4153, March 2007

The Policy Research Working Paper Series disseminates the findings of work in progress to encourage the exchange of ideas about development issues. An objective of the series is to get the findings out quickly, even if the presentations are less than fully polished. The papers carry the names of the authors and should be cited accordingly. The findings, interpretations, and conclusions expressed in this paper are entirely those of the authors. They do not necessarily represent the view of the World Bank, its Executive Directors, or the countries they represent. Policy Research Working Papers are available online at http://econ.worldbank.org.

\footnotetext{
* The opinions presented here are of the authors and thus do not necessarily represent the official position of the institutions they belong to. We are grateful to Maria Cecilia Gáname, Daniel Lederman, James Parks, Alejandro Guerson, and participants at the XLI Annual Meetings of the Argentinean Political Economy Association in Salta. A version of this paper is part of Lucio Castro's Dphil in Economics' dissertation at the University of Sussex.

* Lucio Castro is Senior Economist at Maxwell Stamp PLC; Abbot's Court, Farringdon Lane, London, EC1R 3AX; lcastro@maxwellstamp.com

- Marcelo Olarreaga is Senior Economist at the World Bank’s Office of the Chief Economist for Latin America and the Caribbean, and Research Fellow at the Center for Economic Policy Research in London, molarreaga@worldbank.org

^Daniel Saslavsky is Research Economist at the Center for Production Studies, dsaslavsky@utdt.edu
} 


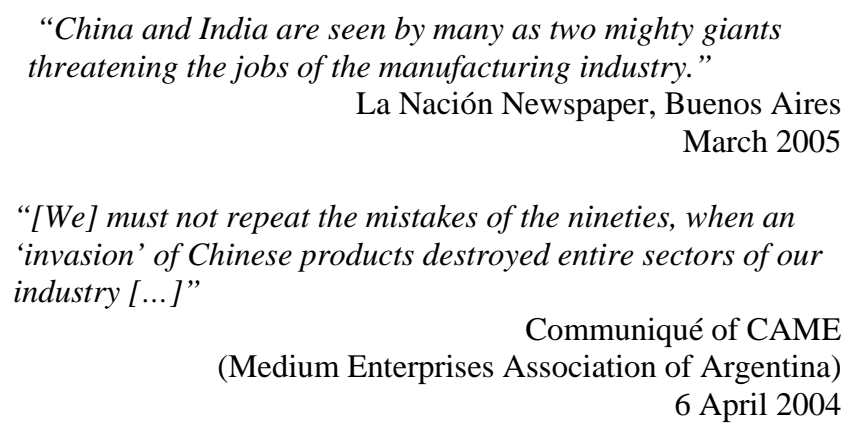

\section{Introduction}

For many in Latin America, the increasing participation of China and India in international markets is seen as a looming shadow of two 'mighty giants' on the region's industrial sector, and one of the major causes behind the significant reduction of employment in the manufacturing industry in the last decade. Are these claims justified? Are China and India the 'mighty giants' driving the secular fall in manufacturing jobs in Latin America?

This paper attempts to provide answers to these questions with a focus on Argentina, which experienced a 31 percent decline in industrial employment over the last decade, while the share of imports from China and India increased six-fold. We apply a dynamic econometric model where labor demand in each industry is a function of wages, the capital stock, prices and productivity. The last two (prices and productivity) are a function of import and export penetration, and will allow us to identify the impact that trade with China and India is having through these two channels on labor demand in Argentina's manufacturing sector.

In principle, trade should affect the level of employment across and within sectors. Empirical research on the impact of trade on employment has found little evidence either way, particularly in developing countries. ${ }^{1}$ Using plant level data for Morocco, Currie and Harrison (1997) find only a small impact of trade liberalization on the

\footnotetext{
${ }^{1}$ See Hoekman and Winters (2005) for a comprehensive survey on the recent empirical evidence on the effects of trade on employment.
} 
level of employment. Revenga (1997) did not find any statistically significant relation between the level of employment and tariff liberalization in the case of Mexico. Márquez and Pages-Serra (1998) examined the relationship between trade liberalization and employment in Latin America and the Caribbean (LAC) and could not find any substantial effect. A comprehensive study by the IADB (2004), using household survey data for 10 LAC countries, did not find a statistically significant association between the two phenomena. De Ferranti, Perry, Lederman and Maloney (2003) confirm this result for several countries in LAC. In a similar study that also contemplates the effects of exchange rate appreciations, Haltiwanger et. al. (2004) did not find robust results on the relationship between trade liberalization and changes in net employment in the region. In their paper on the impact of trade liberalization on income distribution in Colombia, Attanasio et al. (2004) found no evidence of labor reallocation across sectors. Similarly small employment effects in Latin America are reported in Levinsohn (1999) for Chile, Moreira and Nakberg (2000) for Brazil and Gandelman et al. (2005) for Uruguay.

For Argentina, in particular, Galiani and Sanguinetti (2003) only found a small correlation between trade liberalization and the rate of employment in the 1990s. Pessino and Andres (2005) attribute the negative effects of trade liberalization on employment to the distortions and rigidities of Argentina's labor market rather than to trade liberalization. Sánchez and Buttler (2002) point to other explicative factors beyond trade liberalization, such as labor costs, access to credit finance, financial and real shocks, informality, etc.

Other studies, such as Altamir and Beccaria (1999), Beckerman (2000), and Damill, Frenkel and Mauricio (2002) point to the accelerated process of trade liberalization combined with exchange rate appreciation, as the main culprits of the net employment loss suffered by the Argentinean manufacturing sector in the last decade. In sum, the evidence presented in these studies is not conclusive. In this paper, we are not concerned about which policies may have been the cause of that decline, but rather on whether imports from the two rapidly growing Asian economies can explain part of this trend. 
Results suggest that the increase in overall import penetration during the period could only explain a relatively small share of the decline in manufacturing employment. To be more precise, a 1 percent increase in import penetration leads to a 0.07 percent decline in labor demand. Given that import penetration increased by 79 percent over the sample period (1991-2003), the decline in labor demand that can be attributed to the increase in import penetration is around 6 percent. Given that manufacturing employment declined by 31 percent over the sample period, the increase in import penetration can at most explain 20 percent of the observed loss in manufacturing employment. $^{2}$ The other 80 percent had other causes. More importantly, the increased importance of China as a source of imports had an almost negligible marginal impact on the decline in labor demand associated with the increase on overall imports. A 1 percentage point increase in the share of imports from China leads to an additional 0.02 percent decline in the growth of Argentina's labor demand. Thus, the six-fold increase in the share of imports from China over the period (from 1 to 6 percent) could only explain an additional 0.1 to 0.2 percent decline in labor demand. ${ }^{3}$ Moreover, an increase in the share of imports from Brazil of 1 percentage point would have a marginal impact that is twice as large, which arguably is still very small. Perhaps more worrisome, the small negative impact on employment of increased imports from China and Brazil is concentrated in unskilled labor-intensive sectors. Results for India, the European Union and the United States suggest that an increase in the share of imports from these countries do not have an impact on labor demand (beyond the overall impact of import penetration on labor demand). Increases in exports do not seem to have an impact on manufacturing employment regardless of their destination, with the exception of the Indian market.

The remainder of the paper is organized as follows. Section 2 presents some stylized facts of Argentina's trade liberalization and trade with China and India, as well as the

\footnotetext{
${ }^{2}$ Note that this is an overall impact, and obviously in some sectors a larger share of the employment contraction is explained by import growth.

${ }^{3}$ Given that imports from China represented only 5 percent of Argentinean manufacturing imports over the sample period, and that on average imports explain 20 percent of the decline in manufacturing employment, Chinese imports can only explain 1.1 to 1.2 of the decline in manufacturing employment, once we include the larger marginal impact of Chinese imports. Again, in some sectors the contribution of Chinese imports to the decline in manufacturing employment is obviously larger.
} 
evolution of manufacturing employment. Section 3 presents the theoretical model and the empirical strategy. Section 4 presents the results. Section 5 concludes.

\section{Stylized facts}

There has been a continuous decline in manufacturing employment in Argentina since the early 1980s. For the period under examination in this paper -i.e., between 1991 and 2003 - industrial employment declined by 31 percent. $^{4}$ Losses in industrial employment were only partially compensated by an increase in employment in the services sector. The net change on overall employment was negative, resulting in twodigit unemployment rates over most of the period. It is only from 2003 onwards that manufacturing employment has experienced a recovery.

Simultaneously, the aggregate productivity of the industrial sector increased by an average of 6.8 percent for 1991-1999. Productivity increased most in capital-intensive sectors such as iron and steel, electric machinery and transport equipment and least in natural resources and labor-intensive sub-sectors. ${ }^{5}$

In parallel to these changes in the aggregate level of industrial employment, Argentina experienced a deep and fast process of trade liberalization. ${ }^{6}$ The trade-openness coefficient (exports plus imports as a percentage of GDP) went from 6 percent in 1993 to 23.4 percent in 2001, falling to 21.7 percent in 2003 as a result of the economic collapse of Argentina in 2002. Imports as percent of GDP increased from 9 percent in 1990 to 11 percent in 2001, and fell to 8 percent in 2003. Exports as percentage of GDP rose from 7 percent to 12 percent over the period. ${ }^{7}$ For the manufacturing industry, in particular, import penetration increased by almost 79 percent from 1991 to 2003.

\footnotetext{
${ }^{4}$ More dramatically, the manufacturing employment level in 2003 was only 47 percent of its level in 1980.

${ }^{5}$ For a comprehensive analysis of the changes in the Argentine industrial employment see Altimir and Beccaria (1999), and Beccaria, Altimir and Gonzalez Rosada (2003). Dussel Peters (2004) offers a comparative analysis with Mexico and Brazil.

${ }^{6}$ See Berlinski (2004) for a detailed account of the Argentinean trade liberalization process in the 1990s.

${ }^{7}$ These indicators were calculated with data retrieved from ECLAC (2004).
} 
As shown in Table 1, changes in import penetration and share in the industry's total employment varied significantly across manufacturing sub-sectors in the 1990s. However, a clear pattern does not seem to emerge by simply looking at the evolution of these two variables. For instance, sectors such as textiles, apparel and footwear experienced similar increases in import penetration over the period, but the first two sectors saw their share of total manufacturing employment decline, whereas footwear experienced an above-average increase in its share of manufacturing employment. More generally, while import penetration increased for all manufacturing sub-sectors in 1991-2003 relative to 1980-1991, only half of these sub-sectors experienced a contraction in their share in total industrial employment. ${ }^{8}$ This prima-facie evidence suggests that disentangling the impact of imports on employment may not be straightforward.

The growing importance of China and India as a trading partner is a relatively new phenomenon for Argentina. Figure 2a shows that imports from China, and to a lesser extent India, have started representing a non-negligible share of Argentina's imports only in the mid-1990s. Though the share of China in Argentina's total imports remained relatively low, it increased almost six-fold between 1990 and 2003 . Likewise India's share increased almost seven-fold. Figure $2 b$ reports the same information for Argentina's main trade partners: Brazil, the European Union (EU) and the United States. ${ }^{9}$

The already small share of imports from China in total imports declined severely during Argentina's economic collapse in 2001 and only recovered after 2003. Imports from India were not an important share of total imports over the entire period. Imports from India amounted to more than 1 percent of total imports only after 2002.

\footnotetext{
8 In some sectors (i.e. miscellaneous petroleum products and fabricated metal products) the employment contraction is mostly explained by the radical process of privatization of Argentina's public sector in the 1990s.

${ }^{9}$ These three countries accounted for almost 70 percent of Argentina's imports during the period 19802003.
} 
Nevertheless, trade with China and India is mostly inter-industry (that is, trade of goods between different industry classifications) highlighted by very low intraindustry trade indicators. ${ }^{10}$ At the same time, both imports from and exports to these markets are extremely concentrated in a few products. ${ }^{11}$ This suggests that the potential for inter-sector reallocation of labor could be important even when Argentine trade with these Asian economies is relatively small.

Thus, it is important to capture these trends at the industry level. Table 2 shows information on China's import penetration for 28 manufacturing industries between 1980 and 2003. In the 1990s, China's import penetration was concentrated in a few sectors, mostly capital-intensive, such as electric and non-electric machinery, scientific and professional instruments and other manufactures. These sub-sectors are the ones facing more competition from imports from all sources not only from China. Some labor-intensive sectors such as leather and furniture also faced relatively higher import competition from China.

Likewise Table 3 describes import competition from India. Although import competition from India increased slightly in the 1990s vis-à-vis previous decades, it remained at very low levels. In fact, with the exception of industrial chemicals, imports from India represented less than 1 percent of Argentina’s output.

To summarize, the prima-facie evidence regarding the impact of increases in import penetration on employment in Argentina is mixed. Moreover, the rapid growth in imports from China and India is even less likely to have had a significant impact given that they still represent a small share of Argentina's imports. However, this quick look at the data does not obviously imply causality, and can be misleading. It would be misleading if, for example, there is correlation between the evolution of

\footnotetext{
${ }^{10}$ For instance, Castro et.al. (2005) report a Grubel-Lloyd (GL) Coefficient of 0.01 for ArgentinaChina trade in 2003 (and similar or lower figures for previous years). India displays similar values. The GL coefficient is a statistical indicator of the extent of intra-industry trade (IIT) with the world or a partner within an industry or the whole. The GL coefficient ranges from 1 to 0 . A GL coefficient equal to 1 means that all trade in that trade flow is of on intra-industry nature; a GL equal to 0 that trade is purely inter-industry. See Fontaigne and Freudenberg (1997) for a complete explanation of the GL coefficient and its variants.

${ }^{11}$ Castro et.al. (2005), op. cit.
} 
import penetration and import shares from China and India with other forces that had a significant impact on manufacturing employment in Argentina. It would also be misleading in the presence of reverse causality: import penetration might be increasing because employment is declining. To try to identify the role-played by trade and the growth of Argentina's trade with China and India we turn to a more formal empirical model that will help us address these issues.

\section{The model and the empirical strategy}

In order to estimate the impact of changes on import penetration on labor demand, we follow Greenway et. al. (1998) and assume a Cobb-Douglas production function across industry and time:

$$
q_{i t}=A_{i t} k_{i t}^{\alpha} l_{i t}^{\beta}
$$

where $q$ is real output, $k$ is capital stock, $l$ are units of labor employed, and $A$ is a Hicks-neutral productivity term; $\alpha$ and $\beta$ are the share of each factor used in total output. We further assume that labor markets are perfectly competitive so that the bill wage equals the value of output times the labor share in output. Solving the first order condition of profit maximization for labor yields:

$$
l_{i t}=\beta p_{i t} q_{i t} / w_{i t}
$$

where $p$ is the domestic price of the good $i$ and $w$ is the labor wage. By substituting (1) into (2) and rearranging, the equation yields the following expression:

$$
l_{i t}=\beta p_{i t}\left\lfloor A k_{i t}^{\alpha} l_{i t}^{\beta}\right\rfloor w_{i t}
$$

We then solve (3) for labor demand of industry $i$ at time $t$ :

$$
l_{i t}=\left\{\left(p_{i t} \beta \mathrm{Ak}_{\mathrm{it}}^{\alpha}\right) / w_{i t}\right\}^{(1 / 1-\beta)}
$$


In contrast to Greenaway et.al (1998) output-constrained model, equation (4) conditions labor demand not on output but on the capital stock. ${ }^{12}$ Thus, we allow output to vary according to changes in domestic prices associated with changes in trade liberalization. This may be an important channel through which trade affects the level of employment at the industry level. One would expect the impact of import penetration on labor demand to be larger when conditioning on capital rather than on output, as the former allows for the adjustment of output as import penetration changes. By conditioning labor demand on output, the only channel left for changes in import penetration to affect employment is through its impact on total factor productivity (TFP). This is likely to be positive, as it reduces $\mathrm{x}$-inefficiencies when less efficient firms exit and more efficient firms become larger in the industry. By conditioning on capital, we allow imports and exports to affect employment through changes in both TFP and domestic prices leading to changes in output.

More formally, we assume that $A_{i t} p_{i t}$ is a function of import and export penetration:

$$
A p_{i t}=e^{\left(\lambda_{0} T_{i}\right)} M_{i t}^{\left(\lambda_{1}+\left(1 / \eta^{M}\right)\right)} X_{i t}{ }_{\left.i \lambda_{2}+\left(1 / \eta^{x}\right)\right)}
$$

where $T$ is a time trend, $M$ is a measure of import penetration, $X$ is a measure of export penetration, $\eta^{M}$ is the import demand elasticity, $\eta^{X}$ is the export supply elasticity, $\lambda_{0}$ captures a time trend in TFP, $\lambda_{1}$ is the elasticity of TFP with respect to imports, and $\lambda_{2}$ is the elasticity of TFP with respect to exports.

Whilst $\lambda_{1}$ and $\lambda_{2}$ are likely to be positive, as increases in exports and imports are likely to increase TFP. On the other hand $\eta^{M}$ is negative as an increase in imports will decrease $p_{i t}$ (and therefore employment) through this channel, $\eta^{X}$ is positive and therefore an increase in exports will increase $p_{i t}$ (and consequently employment) through this conduit.

Substituting equation (5) into (4) and taking logs, yields:

\footnotetext{
${ }^{12}$ Greenaway et al. (1999) substitute the capital stock in equation (4) by capital demand, which results on labor being a function of output, rather than capital. Their final expression is similar to the one in equation (6) below except that instead of the log of the capital stock they have the log of output.
} 


$$
\ln l_{i t}=\alpha_{0}+\alpha_{1} \ln K_{i t}+\alpha_{2} \ln w_{i t}+\alpha_{3} \ln M_{i t}+\alpha_{4} \ln X_{i t}+\alpha_{5} T+\alpha_{6} I+\varepsilon
$$

Equation (6) is the basis for our empirical model using both industry and time dummies. Time dummies $(T)$ capture not only the time trend of the productivity parameter, but also any general liberalization program that would have occurred (an overall 10 percent cut in tariffs) or increase in tariffs for that matter, as well as the impact of changes in the exchange rate, labor market reforms, or any other macroeconomic shock, such as the 2001 crisis. Industry dummies (I) capture industry particularities, such as the fact that some of the industries (e.g. petroleum products) were subject to significant privatization during the 1990s. So the estimates refer to the within-industry impact of trade liberalization on industry employment, controlling for macroeconomic shocks and the general equilibrium effects of a general trade liberalization with year dummies.

Because we are interested in the impact that Argentina's trade with China and India had on manufacturing employment, we also add to equation (6) their share of total imports and exports, as well as the import and export share of Argentina's three main trading partners (Brazil, the European Union, and the United States) to capture the marginal impact associated with trade with different partners. Finally, we also examine whether unskilled labor tends to be relatively more affected by interacting unskilled and skilled labor dummies with the trade shares.

\subsection{Empirical Strategy}

There are two problems with the estimation of equation (6) that can bias our estimates. First, labor demand is likely to show inertia, and this may lead to first-order serial correlation in the errors. Second, wages and capital stocks are potentially endogenous variables (although theoretically we have treated them as exogenous).

We address the potential serial correlation of the error term by including lagged employment as an explanatory variable, and testing for first and second order correlation of the error term after introducing the lagged dependent variable. This also 
provides us with long run elasticity estimates. However, as shown in the mainstream literature (see Kiviet, 1995), the inclusion of a lagged dependent variable in a panel setting also leads to biased and inconsistent estimates when using ordinary-leastsquares in the presence of fixed effects that might be correlated with the dependent explanatory variable. Thus, we follow Blundell and Bond (1998) and estimate a system GMM using STATA's xtabond2 command. ${ }^{13}$

We address the second problem by using the first, second and third lagged values of wage and capital, as instruments for wages and capital stocks; and the first, second and third lagged values of three additional instruments: a proxy for the average transportation costs associated with imports, sector value added, and the share of lowskilled labor in each industry. ${ }^{14}$

\section{Results}

Table 4 reports the estimates of equation (6) using the System GMM estimator, but also the output-constrained model as in Greenaway et al. (1998). The capitalconstrained model results reported in the first column of Table 5 has the expected signs; wages and capital are statistically significant at 1 percent, as well as the lagged dependent variable. ${ }^{15}$ Capital seems to have a complementary effect on employment, as indicated by the positive sign of its coefficient. ${ }^{16}$ Import penetration is significant at the 5 percent level. According to these results, a 1-percentage point increase in import penetration tends to reduce employment by 0.084 percent in the short run and 0.15 percent in the long run. Export penetration has a positive, but statistically insignificant coefficient.

The second column reports the results of the model where estimates are conditional on output, and again all coefficients have the expected signs. Interestingly, the estimated coefficient on import penetration is 60 percent smaller than in the case of the model

\footnotetext{
${ }^{13}$ See Roodman (2005).

${ }^{14}$ See Data Appendix for a description of the methodology and statistical information used for the construction of each of these variables.variable.

${ }^{15}$ Our estimates for wages and lagged employment are within the range of estimates obtained for other countries in the region using similar specifications. Hamermesh (2004) provides a summary of the results of the existing econometric studies on trade and changes in the derived static and dynamic labour demand in Latin America.

${ }^{16}$ See Hammermesh (1993).
} 
conditional on capital. Note, however, that they are not statistically different from each other.

Note that the null hypothesis of no second order serial correlation of the error term cannot be rejected in both regressions, and the HO hypothesis of no overidentification is rejected. This suggests that there is no evidence that our estimates are biased due to either serial correlation of the error term or lack of identification in our regressions.

Table 5 reports the System GMM estimations only for the capital-constrained specification, but including trade shares by partner, in order to assess the marginal impact of imports and exports with different trading partners. The coefficients on lagged employment, wage and capital stock show the expected signs and are highly significant and stable across specifications. The total import penetration coefficient is always negative and significant around the 1 to 5 percent threshold. As shown, an increase of 1 percentage point in total import penetration generates a job loss of around 0.07 percent. Given that import penetration increased by 79 percent over the sample period (1991-2003), the decline in labor demand that can be attributed to the increase in import penetration is around 6 percent in the short run and 10 percent in the long run. Given that manufacturing employment declined by 31 percent over the sample period (1980-2003), the increase in import penetration can at most explain 32 percent of the observed loss in manufacturing employment. The coefficient on Total Exports/Consumption shows the expected sign, but it is not statistically significant, thus supporting the specification of the models.

The last two columns explore the marginal impact on employment of imports and exports with China, India and Argentina's three main trading partners. In the case of China, the coefficient on imports is negative and significant at the 5 percent level in both columns. This implies that, ceteris paribus, an increase of 1 percentage point in the share of Chinese imports generates a decrease in labor demand of around 0.02 percent (and around 0.04 percent in the long run). Thus, the six-fold increase in the share of imports from China over the period (from 1 to six percent) could explain an almost negligible 0.1 to 0.2 percent additional decline in labor demand. Interestingly, 
an increase in the share of imports from Brazil of 1 percentage point would have an impact that is twice as large, which arguably is still very small. Imports from India, or the European Union and the United States do not appear to have any additional impact on employment levels. Exports to different trading partners do not seem to have any additional impact on employment, except for exports to India, but its economic significance is negligible. Again, all four regressions in Table 5 cannot reject the null hypothesis of no second order serial correlation in the error term and reject the null hypothesis of no over-identification.

Table 6 reports the results for the third column in Table 5, but exploring for heterogeneity across industries’ labor-skill intensity. Results suggest that the marginal (and small) additional impact of imports from both China and Brazil is concentrated in low-skill intensive industries. In the case of China, an increase of 1 percentage point in its import share leads to a decline in the employment of unskilled-intensive sectors of around 0.02 percent. The effect is again twice as large for Brazil. In contrasts, high-skilled sectors seem not to be affected by imports from either China or Brazil. Again, the over-identification and the second order serial correlation tests do not suggest that there are problems with this regression.

\section{Conclusions}

Over the last decade, import penetration in Argentina's manufacturing sector increased by 79 percent, while imports from China and India increased six-fold, and manufacturing employment declined by 33 percent. Many believed that the sharp decline in employment was mainly due to the rapidly growing imports from the two Asian economies. A more careful look suggests that the evidence is mixed at best. Total import competition increased significantly across sectors but manufacturing employment (measured as a share of total employment in the industry) declined in some sub-sectors and increased in others. With the exception of apparel and footwear, employment did not decline in sectors where China and India had a significant and growing share of Argentina’s imports. Moreover, the two Asian economies still only account for less than 6 percent of Argentina's import bundle. 
In order to take a more careful look at whether imports from China and India are responsible for the decline in manufacturing employment in Argentina, we develop a dynamic econometric model, where import penetration and export penetration can affect the level of employment through their impact on domestic prices and productivity, while controlling for industry and time effects.

Results suggest that the rapid increase in import penetration in Argentina's manufacturing employment can only explain a fraction (20 percent) of the large decline in manufacturing employment observed during the period. Imports from China had a slightly larger marginal impact on manufacturing employment than imports from the rest of the world, probably due to the fact that China is a relatively labor abundant country, but given the relatively small size of imports from China compared to the rest of the world, the overall effect of Chinese imports on manufacturing employment remains small. Moreover, the marginal impact of imports from Brazil is twice as large as imports from China, although the economic magnitude is still rather small. Imports from India or Argentina's other two main trading partners (the European Union and the United States) do not seem to have any additional marginal impact (beyond the impact of import penetration) on manufacturing employment.

Imports from both China and India tend to impose larger declines on the level of employment in unskilled-intensive sectors, although again the marginal effect on unskilled employment of imports from Brazil is twice as large as imports from China. Again, imports from other sources do not have a statistically significant impact when exploring the heterogeneity across skilled and unskilled intensive industries.

Perhaps surprisingly, exports do not seem to contribute to manufacturing employment. The coefficient on export penetration is always positive, but never statistically so. Moreover, even if they were statistically significant, the magnitude of the impact is rather small, given the estimated coefficients. This holds regardless of the export destination, with the exception of India, but again the magnitude is 
negligible. This suggests that increases in exports are not accompanied by increases in manufacturing employment.

To conclude, the decline in Argentina's manufacturing employment can only marginally be attributed to import competition from China and India, or from any other source for that matter. The "mighty giants" that could explain this decline are to be found somewhere else. Potential candidates are Argentina's exchange rate policies in the 1990s that made employment in the non-tradeable sector relatively more attractive, and the shift in Argentina's comparative advantage away from manufacturing and towards natural resource and knowledge-intensive sectors. 


\section{Bibliography}

Acosta, P. Y Gasparini, L. (2004). “Capital Accumulation, Trade Liberalization and Rising Wage Inequality: The Case of Argentina”, Documento de trabajo Numero 5, CEDLAS, Universidad Nacional de la Plata, Argentina.

Altimir, O. y Beccaria, L. (1999) "El Mercado de trabajo bajo el nuevo régimen económico en Argentina”, Serie Reformas Económicas 28, CEPAL, Buenos Aires, Julio.

Arellano, M. and Bond, S. (1991) "Some tests of specification for panel data”, Review of Economic Studies, 70, 33-58.

Beccaria, Altimir and Gonzalez Rosada (2003) Economia Laboral y politicas de empleo, CEPAL, Buenos Aires.

Berlinsky, J. (2004) Los Impactos de la Política Comercial: Argentina y Brasil, 19881997, Siglo Veintiuno de Argentina Editores, Buenos Aires.

Bernard, A., Jensen, J.B. and Schott, P. (2003) "Survival of the best fit: exposure to lowwage countries and the (uneven) growth of US manufacturing plants," IFS Working Papers W03/12, Institute for Fiscal Studies.

Blundell, R. and S. Bond (1998), "Initial conditions and Moment Restrictions in Dynamic Panel Data Models”, Journal of Econometrics 87:115-144.

Castro, L., Monat, P. and Tramutola (h), C. (2005), China: Como puede la Argentina aprovechar la gran oportunidad. Edhasa Editorial, Buenos Aires, December.

Damill, M., Frenkel, R, y Maurizio, R. (2002) “Argentina: A decade of currency board. An analysis of growth, employment and income distribution”, Employment Paper 2002/42, Employment Sector, International Labor Office, Geneva. 
Dussel Peters, E. (2004) "Efectos de la apertura comercial en el empleo y el mercado laboral de México y sus diferencias con Argentina y Brasil (1990-2003)”, Documentos de Estrategias de Empleo 2004/10, Unidad de Análisis e Investigación sobre el Empleo, Departamento de Estrategias de Empleo, Oficina Internacional del Trabajo (OIT), Ginebra.

ECLAC (2004) Statistical Yearbook for Latin America and the Caribbean, http://www.eclac.cl/badestat/anuario_2004/eng.htm

Fajnzylber, P. y Maloney, W.F. (2001) “How Comparable are Labor Demand Elasticities across Countries?” World Bank, Washington DC.

Fajnzylver, P. y Malloney, W.F. (2000) "Labor Demand and Trade Reform in Latin America”, World Bank Working Paper 2491, World Bank, Washington DC.

Galiani, S. and P. Sanguinetti (2003), “The impact of trade liberalization on wage inequality evidence from Argentina”, Journal of Development Economics 72, 497-513.

Goldberg, P.K. and Pavnick, N. (2004) “Trade, Inequality, and Poverty: What Do We Know? Evidence from Recent Trade Liberalization Episodes in Developing Countries” NBER Working Paper No. 10593.

Greenaway, D., Hine, R.C. and Wright, P. (1999) “An Empirical Assessment of the Impact of Trade on Employment in the United Kingdom”, European Journal of Political Economy 15(3), 485-500.

Haltinwanger, J., Kugler, A., Kugler, M., Micco, A. y Pages, C. (2004) “Effects of Tariffs and Real Exchange Rates on Job Reallocation: Evidence from Latin America”, Policy Reform 7(4), 201-218.

Hamermesh, D. H. (1993) Labor Demand, Princeton University Press, Princeton, New Jersey. 
Hamermesh, D. H. (2004) "Labor Demand in Latin America and the Caribbean: What Does It Tell Us?” in Law and Employment: Lessons from Latin America and the Caribbean, Heckman, J.J. and Pagés, C. (eds.), The University of Chicago Press, Chicago.

Hsiao, C. (1986). “Analysis of Panel Data”, Econometric Society Monographs No 11,Cambridge University Press.

IADB (2004) “IPES 2004: Se buscan buenos empleos: los mercados laborales de América Latina”, Departamento de Investigaciones, Banco Interamericano de Desarrollo, Washington D.C.

Kiviet, J. (1995) “On bias, inconsistency, and efficiency of various estimators in dynamic panel data models”, Journal of Econometrics 68 (1), 53-78.

Kletzer, L. (2001) Job Loss from Imports: Measuring the Costs, Institute for International Economics, Washington DC, September.

Pessino, C. and Andres, L. (2005) “Creación y destrucción de empleos en Argentina” en ¿Para bien o para mal? Debate sobre el impacto de la globalización en los mercados de trabajo de América Latina, Márquez, G. (ed.), IADB, Washington DC.

Revenga, A. (1997) “Employment and Wage Effects of Trade Liberalization: The Case of Mexican Manufacturing” Journal of Labor Economics 15 (3), S20-S43.

Roodman, D. (2005), "xtabond2: Stata module to extend xtabond dynamic panel data estimator.” Center for Global Development. Washington, DC.

Sánchez, G. y Butler, I. (2004) “Market Institutions, Labor Market Dynamics and Productivity in Argentina during the 1990s”, IERAL-Fundación Mediterránea, Cordoba. 


\section{Data Appendix: Sources and variable construction}

Our main source is the UNIDO INDSTAT Database of Industrial Statistics at the 3digit, ISIC Revision 2 nomenclature. It comprises output, wages, employment and value added data for 28 manufacturing sectors, covering the years 1980-2003. The latter was used as an instrument in our estimations. All variables (except for the number of employed people) were converted to 1976 constant dollars using a GDP deflator retrieved from the US BEA (Bureau of Economic Analysis).

In addition, we computed an initial capital stock using the ECLAC-PADI database, adjusted later using (scarce) gross fixed investment data found in the UNIDO database by applying the permanent inventory method with a 10 percent depreciation rate. Trade data was gathered from UN COMTRADE and then converted to 1976 constant dollars, except for transport costs, later used as an additional instrument in our econometric estimations. We calculated freight costs per mile using US Imports data from Argentina, gathered from US ITC and BLS sources. Then, we computed total freight costs multiplying freight costs per mile by each trading partner's distance to Argentina using the CEPII distance database. Finally, we applied a simple average in order to avoid collinearity issues with other explanatory variables.

Another variable of interest used as instrument in our estimations is the share of unskilled workers by industrial sector. This was gathered from INDEC (National Institute of Statistics and Census), using all household surveys (EPH) available for Greater Buenos Aires. Any person with unfinished secondary education or less was considered low skilled. Missing data were filled with the averages of immediate passed and future observations, since it is highly unlikely to encounter dramatic structural changes in the skill intensity of each industry from one year to another. 


\section{Summary of Data: Available years and Sources}

\begin{tabular}{|c|c|c|}
\hline Variable & Years & Sources \\
\hline $\begin{array}{l}\text { Output } \\
\text { Employment } \\
\text { Wages } \\
\text { Value Added }\end{array}$ & $1980-2003$ & UNIDO INDSTAT Database \\
\hline Capital Stock & $1980-2003$ & $\begin{array}{l}\text { ECLAC-PADI / UNIDO } \\
\text { INDSTAT }\end{array}$ \\
\hline Transport Cost & $1991-2003$ & $\begin{array}{l}\text { US ITC (International Trade } \\
\text { Commission), BLS (Bureau of } \\
\text { Labor Statistics), CEPII distance } \\
\text { database, UN COMTRADE }\end{array}$ \\
\hline Imports and Exports & $1980-2003$ & UN COMTRADE \\
\hline Share of Low Skill Workers & $1990-2003$ & $\begin{array}{l}\text { INDEC (National Institute of } \\
\text { Statistics and Census) - EPH - } \\
\text { Greater Buenos Aires }\end{array}$ \\
\hline
\end{tabular}

\section{Variables}

1. Total Import Penetration: Total Import penetration for sector $i$ in year $t$ is defined by the ratio between Imports (M) from a specific partner $p$ (in our case the World) and apparent consumption, calculated as

$$
\text { Penetration }^{p}{ }_{i t}=\frac{M^{p}{ }_{i t}}{Q_{i t}-X_{i t}+M_{i t}}
$$

where the expression in the denominator is apparent consumption. 
2. Total Exports / Consumption: Total Exports / Consumption ratio for sector $i$ in year $t$ is defined by the ratio between Exports (X) from a specific partner $p$ (in our case the World) and Consumption

$$
\text { Export / Consumption }{ }^{p}{ }_{i t}=\frac{X^{p}{ }_{i t}}{Q_{i t}-X_{i t}+M_{i t}}
$$

3. Share of Imports by trading partner: is the ratio of imports $\mathrm{M}$ from partner $p$ and Total Imports for each manufacturing sector $i$ and year $t$.

$$
S^{I, p}{ }_{i t}=\frac{M^{p}{ }_{i t}}{\sum_{p} M_{i t}^{p}}
$$

4. Share of Exports by trading partner: is the ratio of exports $X$ to partner $p$ and Total Exports for each manufacturing sector $i$ and year $t$.

$$
S^{X, p}{ }_{i t}=\frac{X^{p}{ }_{i t}}{\sum_{p} X_{i t}^{p}}
$$

5. Low / High Skill: Low (High) Skill is a dichotomous variable that takes a value of 1 when a particular sector $i$ in year $t$ has a lower (higher) share of Low (High) Skilled workers compared to the industry average. 


\section{Tables and Figures}

Figure 1: Employment in the Argentine Industrial Sector, 1980-2003 (thousands of workers)

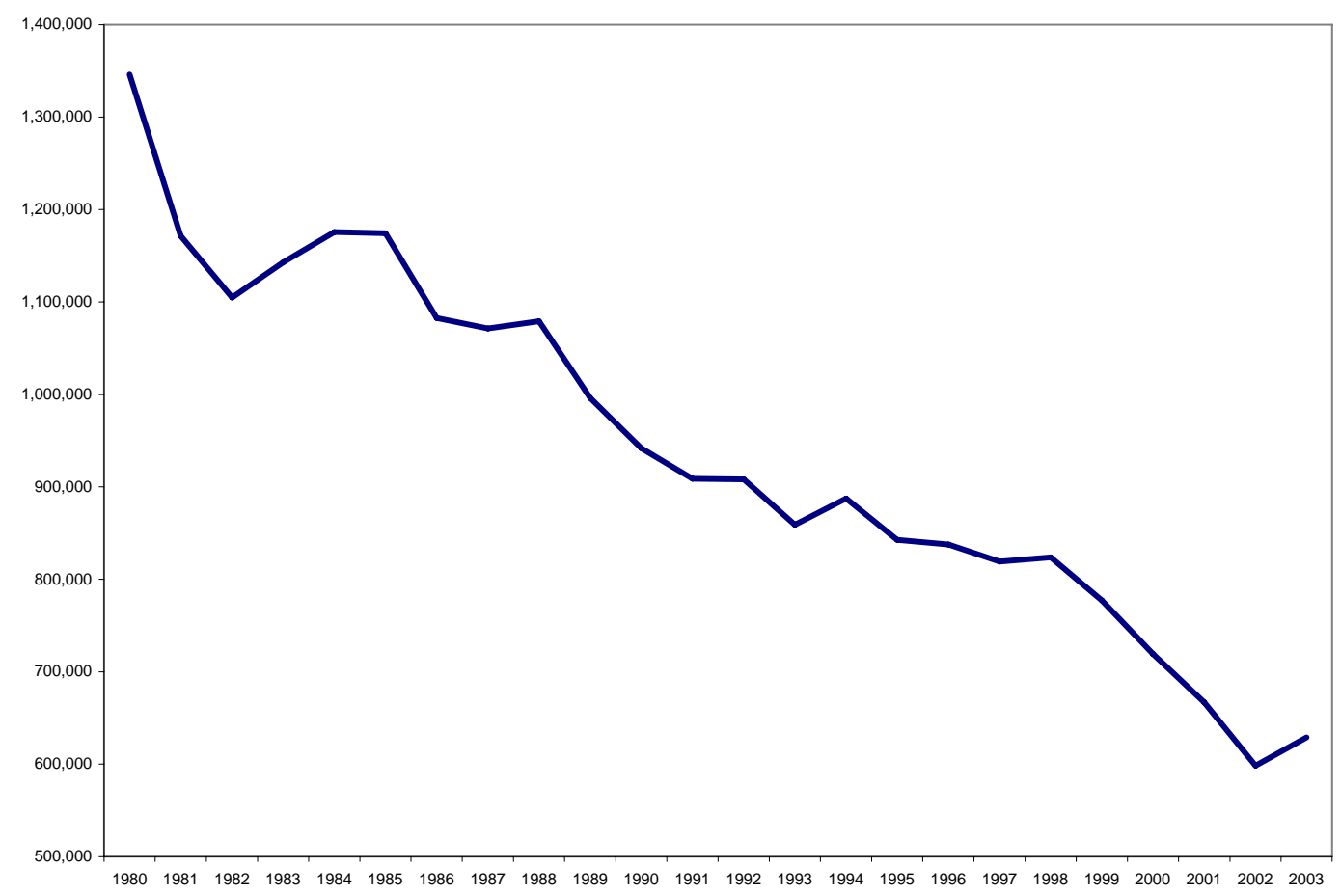

Source: UNIDO (2004) 
Figure 2a: Share of Argentine Imports from China and India, 1980-2003

Source: UN COMTRADE (2005)

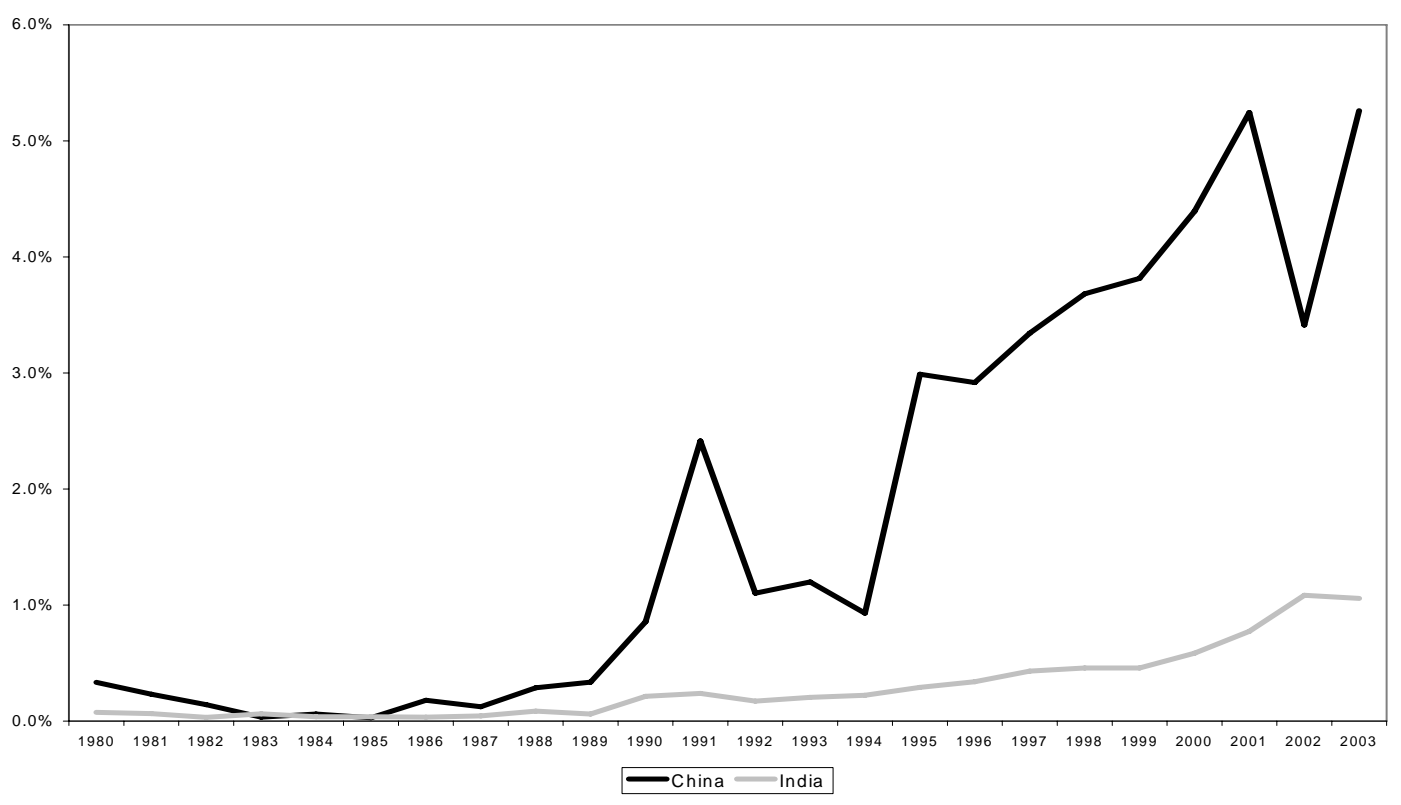

Figure 2b: Share of Argentine Imports from Brazil, EU and USA, 1980-2003

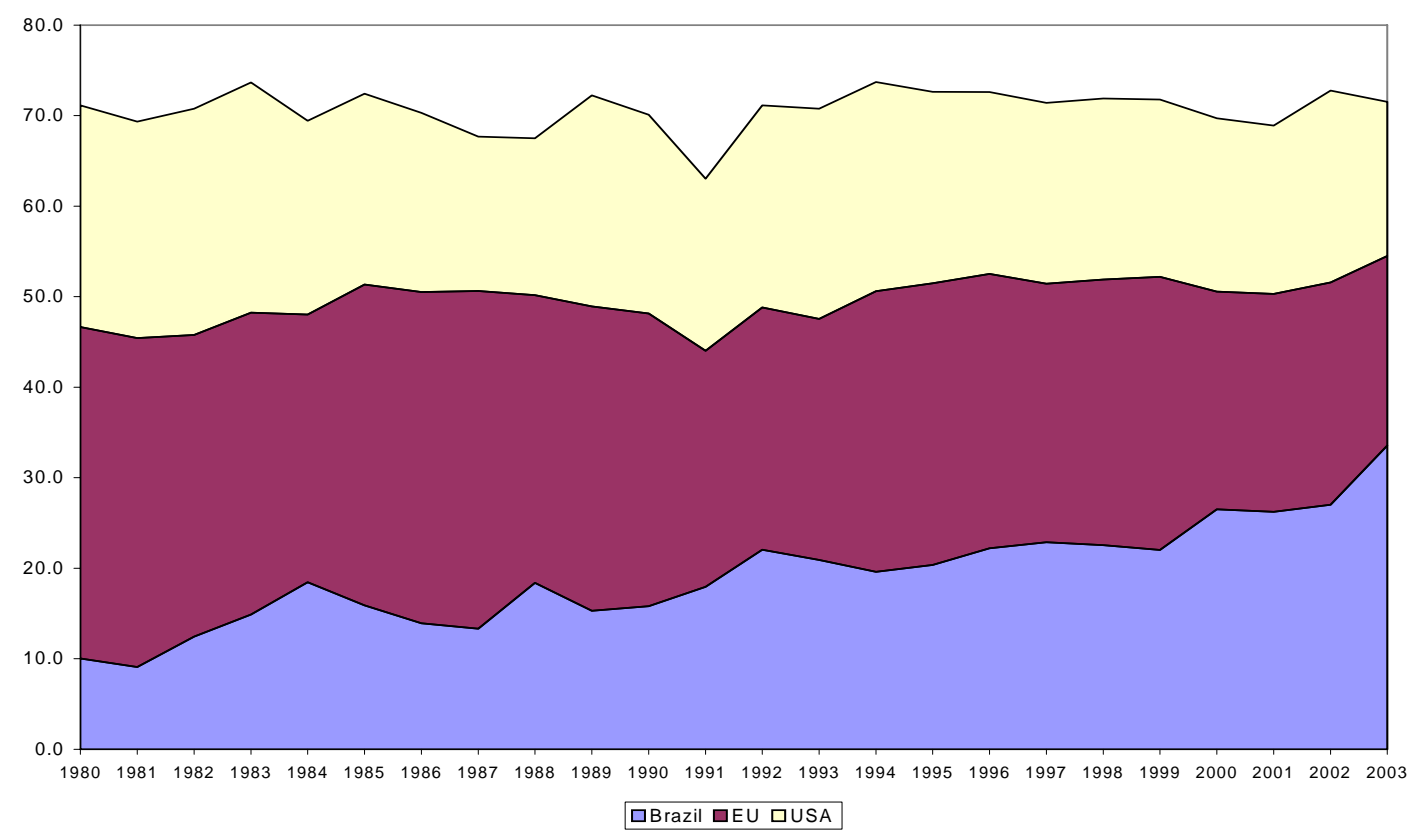

Source: UN COMTRADE (2005) 
Table 1: Total Import Penetration and Changes in Industry's Share in Total Industrial Employment, Percent and Averages

\begin{tabular}{|c|c|c|c|c|c|}
\hline ISIC & Industry Description & $1980-1990$ & 1991-2000 & 2001-2003 & $\begin{array}{c}\text { Changes in } \\
\text { Industry's } \\
\text { Share in } \\
\text { Total } \\
\text { Industrial } \\
\text { Employment } \\
1991-03 \\
\end{array}$ \\
\hline 311 & Food products & $1.0 \%$ & $3.8 \%$ & $2.7 \%$ & $21.79 \%$ \\
\hline 313 & Beverages & $0.7 \%$ & $1.6 \%$ & $0.5 \%$ & $57.26 \%$ \\
\hline 314 & Tobacco & $0.3 \%$ & $0.1 \%$ & $0.5 \%$ & $25.58 \%$ \\
\hline 321 & Textiles & $1.7 \%$ & $12.4 \%$ & $11.7 \%$ & $-24.83 \%$ \\
\hline 322 & Wearing apparel, except footwear & $1.2 \%$ & $6.5 \%$ & $4.2 \%$ & $-3.18 \%$ \\
\hline 323 & Leather products & $0.9 \%$ & $12.0 \%$ & $11.3 \%$ & $26.14 \%$ \\
\hline 324 & Footwear, except rubber or plastic & $0.8 \%$ & $10.7 \%$ & $6.0 \%$ & $60.55 \%$ \\
\hline 331 & Wood products, except furniture & $8.2 \%$ & $16.4 \%$ & $12.3 \%$ & $-21.45 \%$ \\
\hline 332 & Furniture, except metal & $0.2 \%$ & $11.4 \%$ & $18.0 \%$ & $6.64 \%$ \\
\hline 341 & Paper and products & $8.2 \%$ & $19.8 \%$ & $15.9 \%$ & $22.18 \%$ \\
\hline 342 & Printing and publishing & $1.9 \%$ & $4.2 \%$ & $2.8 \%$ & $29.20 \%$ \\
\hline 351 & Industrial chemicals & $24.2 \%$ & $40.0 \%$ & $41.7 \%$ & $-19.20 \%$ \\
\hline 352 & Other chemicals & $6.0 \%$ & $12.4 \%$ & $13.0 \%$ & $31.87 \%$ \\
\hline 353 & Petroleum refineries & $1.7 \%$ & $5.4 \%$ & $4.9 \%$ & $4.55 \%$ \\
\hline 354 & Miscellaneous petroleum and coal products & $5.8 \%$ & $25.9 \%$ & $28.0 \%$ & $-92.83 \%$ \\
\hline 355 & Rubber products & $4.3 \%$ & $28.8 \%$ & $33.5 \%$ & $1.69 \%$ \\
\hline 356 & Plastic products & $2.6 \%$ & $12.5 \%$ & $8.2 \%$ & $64.30 \%$ \\
\hline 361 & Pottery, china, earthenware & $2.0 \%$ & $13.8 \%$ & $13.1 \%$ & $-74.63 \%$ \\
\hline 362 & Glass and products & $5.0 \%$ & $18.5 \%$ & $15.5 \%$ & $-8.14 \%$ \\
\hline 369 & Other non-metallic mineral products & $3.9 \%$ & $5.3 \%$ & $3.3 \%$ & $-54.09 \%$ \\
\hline 371 & Iron and steel & $14.5 \%$ & $16.2 \%$ & $29.7 \%$ & $-35.58 \%$ \\
\hline 372 & Non-ferrous metals & $19.7 \%$ & $29.5 \%$ & $33.1 \%$ & $-16.16 \%$ \\
\hline 381 & Fabricated metal products & $3.8 \%$ & $16.1 \%$ & $14.6 \%$ & $-37.68 \%$ \\
\hline 382 & Machinery, except electrical & $28.8 \%$ & $55.3 \%$ & $45.7 \%$ & $21.46 \%$ \\
\hline 383 & Machinery, electric & $23.0 \%$ & $49.0 \%$ & $48.2 \%$ & $5.96 \%$ \\
\hline 384 & Transport equipment & $7.6 \%$ & $35.5 \%$ & $44.2 \%$ & $-27.54 \%$ \\
\hline 385 & Professional and scientific equipment & $43.7 \%$ & $61.8 \%$ & $70.9 \%$ & $-4.52 \%$ \\
\hline 390 & Other manufactured products & $23.8 \%$ & $60.3 \%$ & $55.3 \%$ & $-18.61 \%$ \\
\hline
\end{tabular}

Source: Own calculations based on UNIDO (2004) and UNCOMTRADE (2005) 
Table 2: Import Penetration from China, Percent and Averages

\begin{tabular}{|c|c|c|c|c|}
\hline ISIC & Industry description & $1980-1990$ & 1991-2000 & 2001-2003 \\
\hline 311 & Food products & $0.00 \%$ & $0.02 \%$ & $0.02 \%$ \\
\hline 313 & Beverages & $0.00 \%$ & $0.00 \%$ & $0.00 \%$ \\
\hline 314 & Tobacco & $0.00 \%$ & $0.00 \%$ & $0.00 \%$ \\
\hline 321 & Textiles & $0.07 \%$ & $0.65 \%$ & $0.36 \%$ \\
\hline 322 & Wearing apparel, except footwear & $0.02 \%$ & $1.25 \%$ & $0.82 \%$ \\
\hline 323 & Leather products & $0.01 \%$ & $4.77 \%$ & $5.30 \%$ \\
\hline 324 & Footwear, except rubber or plastic & $0.01 \%$ & $1.85 \%$ & $0.56 \%$ \\
\hline 331 & Wood products, except furniture & $0.00 \%$ & $0.22 \%$ & $0.23 \%$ \\
\hline 332 & Furniture, except metal & $0.00 \%$ & $0.36 \%$ & $1.13 \%$ \\
\hline 341 & Paper and products & $0.00 \%$ & $0.02 \%$ & $0.03 \%$ \\
\hline 342 & Printing and publishing & $0.00 \%$ & $0.09 \%$ & $0.08 \%$ \\
\hline 351 & Industrial chemicals & $0.05 \%$ & $0.63 \%$ & $1.50 \%$ \\
\hline 352 & Other chemicals & $0.01 \%$ & $0.15 \%$ & $0.14 \%$ \\
\hline 353 & Petroleum refineries & $0.00 \%$ & $0.00 \%$ & $0.01 \%$ \\
\hline 354 & Miscellaneous petroleum and coal products & $0.00 \%$ & $0.00 \%$ & $0.01 \%$ \\
\hline 355 & Rubber products & $0.00 \%$ & $0.45 \%$ & $0.97 \%$ \\
\hline 356 & Plastic products & $0.01 \%$ & $0.98 \%$ & $0.71 \%$ \\
\hline 361 & Pottery, china, earthenware & $0.06 \%$ & $3.13 \%$ & $2.95 \%$ \\
\hline 362 & Glass and products & $0.00 \%$ & $0.44 \%$ & $0.76 \%$ \\
\hline 369 & Other non-metallic mineral products & $0.00 \%$ & $0.05 \%$ & $0.10 \%$ \\
\hline 371 & Iron and steel & $0.00 \%$ & $0.14 \%$ & $0.93 \%$ \\
\hline 372 & Non-ferrous metals & $0.00 \%$ & $0.15 \%$ & $0.57 \%$ \\
\hline 381 & Fabricated metal products & $0.02 \%$ & $0.86 \%$ & $1.19 \%$ \\
\hline 382 & Machinery, except electrical & $0.01 \%$ & $1.17 \%$ & $2.94 \%$ \\
\hline 383 & Machinery, electric & $0.02 \%$ & $2.21 \%$ & $4.75 \%$ \\
\hline 384 & Transport equipment & $0.02 \%$ & $0.31 \%$ & $0.64 \%$ \\
\hline 385 & Professional and scientific equipment & $0.14 \%$ & $2.10 \%$ & $3.64 \%$ \\
\hline 390 & Other manufactured products & $0.56 \%$ & $10.51 \%$ & $13.88 \%$ \\
\hline
\end{tabular}

Source: Own calculations based on UNIDO (2004) and UNCOMTRADE (2005)

Notes: in bold are import penetration coefficients higher than $1 \%$ 
Table 3: Indian Imports Penetration, Percent and Averages

\begin{tabular}{|c|c|c|c|c|}
\hline ISIC & Industry description & 1980-1990 & 1991-2000 & 2001-2003 \\
\hline 311 & Food products & $0.0 \%$ & $0.0 \%$ & $0.0 \%$ \\
\hline 313 & Beverages & $0.0 \%$ & $0.0 \%$ & $0.0 \%$ \\
\hline 314 & Tobacco & $0.0 \%$ & $0.0 \%$ & $0.0 \%$ \\
\hline 321 & Textiles & $0.0 \%$ & $0.2 \%$ & $0.2 \%$ \\
\hline 322 & Wearing apparel, except footwear & $0.0 \%$ & $0.2 \%$ & $0.2 \%$ \\
\hline 323 & Leather products & $0.0 \%$ & $0.1 \%$ & $0.1 \%$ \\
\hline 324 & Footwear, except rubber or plastic & $0.0 \%$ & $0.0 \%$ & $0.0 \%$ \\
\hline 331 & Wood products, except furniture & $0.0 \%$ & $0.0 \%$ & $0.0 \%$ \\
\hline 332 & Furniture, except metal & $0.0 \%$ & $0.0 \%$ & $0.0 \%$ \\
\hline 341 & Paper and products & $0.0 \%$ & $0.0 \%$ & $0.0 \%$ \\
\hline 342 & Printing and publishing & $0.0 \%$ & $0.0 \%$ & $0.0 \%$ \\
\hline 351 & Industrial chemicals & $0.0 \%$ & $0.4 \%$ & $1.3 \%$ \\
\hline 352 & Other chemicals & $0.0 \%$ & $0.1 \%$ & $0.1 \%$ \\
\hline 353 & Petroleum refineries & $0.0 \%$ & $0.0 \%$ & $0.1 \%$ \\
\hline 354 & Miscellaneous petroleum and coal products & $0.0 \%$ & $0.0 \%$ & $0.0 \%$ \\
\hline 355 & Rubber products & $0.0 \%$ & $0.2 \%$ & $0.3 \%$ \\
\hline 356 & Plastic products & $0.0 \%$ & $0.0 \%$ & $0.0 \%$ \\
\hline 361 & Pottery, china, earthenware & $0.0 \%$ & $0.0 \%$ & $0.0 \%$ \\
\hline 362 & Glass and products & $0.0 \%$ & $0.0 \%$ & $0.0 \%$ \\
\hline 369 & Other non-metallic mineral products & $0.0 \%$ & $0.0 \%$ & $0.0 \%$ \\
\hline 371 & Iron and steel & $0.0 \%$ & $0.0 \%$ & $0.2 \%$ \\
\hline 372 & Non-ferrous metals & $0.0 \%$ & $0.0 \%$ & $0.0 \%$ \\
\hline 381 & Fabricated metal products & $0.0 \%$ & $0.1 \%$ & $0.1 \%$ \\
\hline 382 & Machinery, except electrical & $0.0 \%$ & $0.0 \%$ & $0.0 \%$ \\
\hline 383 & Machinery, electric & $0.0 \%$ & $0.0 \%$ & $0.0 \%$ \\
\hline 384 & Transport equipment & $0.0 \%$ & $0.2 \%$ & $0.1 \%$ \\
\hline 385 & Professional and scientific equipment & $0.0 \%$ & $0.1 \%$ & $0.1 \%$ \\
\hline 390 & Other manufactured products & $0.0 \%$ & $0.1 \%$ & $0.2 \%$ \\
\hline
\end{tabular}

Source: Own calculations based on UNIDO (2004) and UNCOMTRADE (2005). Notes: in bold are import penetration coefficients higher than $1 \%$ 
Table 4

\begin{tabular}{|c|c|c|}
\hline Employment & $\begin{array}{c}(1) \\
\text { Capital } \\
\text { constrained }\end{array}$ & $\begin{array}{c}\text { (3) } \\
\text { Output } \\
\text { constrained }\end{array}$ \\
\hline Employment (-1) & $\begin{array}{c}\mathbf{0 . 4 5 6} \\
(0.052)^{* * *}\end{array}$ & $\begin{array}{c}\mathbf{0 . 1 8 7} \\
(0.037)^{* * *}\end{array}$ \\
\hline Wage & $\begin{array}{c}-\mathbf{0 . 2 7 9} \\
(0.040)^{* * *}\end{array}$ & $\begin{array}{c}\mathbf{- 0 . 2 8} \\
(0.024)^{* * *}\end{array}$ \\
\hline Capital or Output & $\begin{array}{c}0.222 \\
(0.039)^{* * *}\end{array}$ & $\begin{array}{c}\mathbf{0 . 6 2 4} \\
(0.059)^{* * *}\end{array}$ \\
\hline Total Import Penetration & $\begin{array}{c}\mathbf{- 0 . 0 8 4} \\
(0.033)^{* *}\end{array}$ & $\begin{array}{c}\mathbf{- 0 . 0 5 0} \\
(0.022)^{* *}\end{array}$ \\
\hline Total Export Penetration & $\begin{array}{c}0.007 \\
(0.019)\end{array}$ & $\begin{array}{c}\mathbf{0 . 0 2 9} \\
(0.013)^{* *}\end{array}$ \\
\hline Constant & $\begin{array}{c}3.397 \\
(1.390)^{* *}\end{array}$ & $\begin{array}{c}1.424 \\
(1.051)\end{array}$ \\
\hline 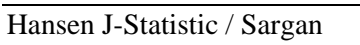 & 0.0 & 0.07 \\
\hline 2nd Order AC Test (p-value) & 0.63 & 0.80 \\
\hline \multicolumn{3}{|c|}{$\begin{array}{l}\text { Time and Sector Dummies included in all regressions but not reported Robus } \\
\text { Standard Error in Parenthesis. }(* * *) \text { : Significant at } 1 \% ;(* *) \text { : Significant at } 5 \% \text {; } \\
(*) \text { : Significant at } 10 \% \text { System GMM correspond to one step estimation. The } \\
\text { instrumental variables used are a proxy for the average transportation costs } \\
\text { associated with imports, sector value added, and the share of low-skilled labor } \\
\text { in each industry. }\end{array}$} \\
\hline
\end{tabular}


Table 5

\begin{tabular}{|c|c|c|c|c|}
\hline Dependent Variable: Employment & (1) & (2) & (3) & (4) \\
\hline Employment (-1) & $\begin{array}{c}0.493 \\
(0.0536)^{* * *}\end{array}$ & $\begin{array}{c}0.459 \\
(0.0558)^{* * *}\end{array}$ & $\begin{array}{c}0.453 \\
(0.513)^{* * *}\end{array}$ & $\begin{array}{c}0.456 \\
(0.048)^{* * *}\end{array}$ \\
\hline Wage & $\begin{array}{c}-0.276 \\
(0.0388)^{* * *}\end{array}$ & $\begin{array}{c}-0.276 \\
(0.0388)^{* * *}\end{array}$ & $\begin{array}{c}-0.281 \\
(0.0453)^{* * *}\end{array}$ & $\begin{array}{c}-0.295 \\
(0.047)^{* * *}\end{array}$ \\
\hline Capital & $\begin{array}{c}0.238 \\
(0.0414)^{* * *}\end{array}$ & $\begin{array}{c}0.218 \\
(0.0357)^{* * *}\end{array}$ & $\begin{array}{c}0.230 \\
(0.415)^{* * *}\end{array}$ & $\begin{array}{c}0.255 \\
(0.047)^{* * *}\end{array}$ \\
\hline Import Penetration & & $\begin{array}{c}-0.081 \\
(0.0316)^{* *}\end{array}$ & $\begin{array}{c}-0.071 \\
(0.0333)^{* *}\end{array}$ & $\begin{array}{c}-0.067 \\
(0.032)^{* *}\end{array}$ \\
\hline Share of Imports from China & & & $\begin{array}{c}-0.018 \\
(0.009)^{* *}\end{array}$ & $\begin{array}{c}-0.017 \\
(0.008)^{* *}\end{array}$ \\
\hline Share of Imports from Brazil & & & $\begin{array}{c}-0.040 \\
(0.012)^{* *}\end{array}$ & $\begin{array}{c}-0.038 \\
(0.014)^{* * *}\end{array}$ \\
\hline Share of Imports from EU+USA & & & $\begin{array}{c}-0.048 \\
(0.0282)\end{array}$ & $\begin{array}{l}-0.047 \\
(0.033)\end{array}$ \\
\hline Share of Imports from India & & & $\begin{array}{c}0.004 \\
(0.0079)\end{array}$ & $\begin{array}{c}0.001 \\
(0.007)\end{array}$ \\
\hline Export Penetration & & & & $\begin{array}{c}0.026 \\
(0.022)\end{array}$ \\
\hline Share of Exports to China & & & & $\begin{array}{l}0.001 \\
(0.003)\end{array}$ \\
\hline Share of Exports to Brazil & & & & $\begin{array}{c}0.009 \\
(0.011)\end{array}$ \\
\hline Share of Exports to EU+USA & & & & $\begin{array}{c}0.005 \\
(0.005)\end{array}$ \\
\hline Share of Exports to India & & & & $\begin{array}{c}0.017 \\
(0.007)^{* *}\end{array}$ \\
\hline Constant & $\begin{array}{c}2.687 \\
(1.496)^{*}\end{array}$ & $\begin{array}{c}3.469 \\
(1.198)^{* * *}\end{array}$ & $\begin{array}{c}3.063 \\
(1.245)^{* *}\end{array}$ & $\begin{array}{c}2.464 \\
(1.439)^{*}\end{array}$ \\
\hline Hansen J-Statistic / Sargan & 0.02 & 0.01 & 0.0 & 0.0 \\
\hline 2nd Order AC & 0.78 & 0.66 & 0.77 & 0.54 \\
\hline
\end{tabular}

Sample: 1991-2003

Observations: 364

Notes: Time and Sector Dummies included in all regressions but not reported. Robust Standard Error in Parenthesis. $\left({ }^{* *}\right)$ : Significant at $1 \% ;\left({ }^{* *}\right)$ : Significant at 5\%; $(*)$ : Significant at $10 \%$ System GMM correspond to one step estimation. The instrumental variables used are a proxy for the average transportation costs associated with imports, sector value added, and the share of low-skilled labor in each industry. 
Table 6

\begin{tabular}{|c|c|}
\hline Dependent Variable: Employment & $(1)$ \\
\hline Employment (-1) & $\begin{array}{c}0.461 \\
(0.062)^{* * *}\end{array}$ \\
\hline Wage & $\begin{array}{c}-0.279 \\
(0.043)^{* * *}\end{array}$ \\
\hline Capital & $\begin{array}{c}0.230 \\
(0.039)^{* * *}\end{array}$ \\
\hline Import Penetration & $\begin{array}{c}-0.071 \\
(0.033)^{*}\end{array}$ \\
\hline Share of Imports from China * Low Skill & $\begin{array}{c}-0.018 \\
(0.010)^{*}\end{array}$ \\
\hline Share of Imports from China * High Skill & $\begin{array}{l}-0.016 \\
(0.011)\end{array}$ \\
\hline Share of Imports from Brazil * Low Skill & $\begin{array}{c}-0.038 \\
(0.012)^{* *}\end{array}$ \\
\hline Share of Imports from Brazil * High Skill & $\begin{array}{l}-0.029 \\
(0.035)\end{array}$ \\
\hline Share of Imports from EU+USA * Low Skill & $\begin{array}{l}-0.044 \\
(0.028)\end{array}$ \\
\hline Share of Imports from EU+USA * High Skill & $\begin{array}{l}-0.049 \\
(0.045)\end{array}$ \\
\hline Share of Imports from India * Low Skill & $\begin{array}{l}0.004 \\
(0.006)\end{array}$ \\
\hline Share of Imports from India * High Skill & $\begin{array}{c}0.005 \\
(0.012)\end{array}$ \\
\hline Constant & $\begin{array}{c}3.012 \\
(1.245)^{* *}\end{array}$ \\
\hline Hansen J-Statistic / Sargan & 0.0 \\
\hline 2nd Order AC & 0.83 \\
\hline
\end{tabular}

Sample: 1991-2003

Observations: 364

Notes: Time and Sector Dummies included in all regressions but not reported. Robust Standard Error in Parenthesis. (***): Significant at 1\%; (**): Significant at 5\%; $(*)$ : Significant at $10 \%$ System GMM correspond to one step estimation. The instrumental variables used are a proxy for the average transportation costs associated with imports, sector value added, and the share of low-skilled labor in each industry. 